\title{
INVESTIGATION OF THE STRESS INDEX, GENERAL HEALTH AND AFFECTING PARAMETERS OF STUDENT NURSES IN TURKEY
}

\author{
Gülden Aynacı ${ }^{1}$ iD
}

${ }^{1}$ Trakya University Health Science Undergraduate School, Obstetrics and Gynecology, Edirne, TURKEY

Gülden Aynacı, Dr. Öğr. Üyesi

İletişim: Gülden Aynacı

Trakya University Health Science Undergraduate School, Obstetrics and Gynecology, Edirne, TURKEY

Tel: $02842357885 / 127$

E-Posta: guldenaynaci@hotmail.com
Gönderilme Tarihi : 20 Ağustos 2019

Revizyon Tarihi : 23 Eylül 2019

Kabul Tarihi : 01 Ekim 2019
TÜRKIYE'DEKi HEMSIRELLiK ÖĞRENCILERINDE STRES ENDEKSI VE ETKILEYEN PARAMETRELER İLE GENEL IYiLiK HALININ INCELENMESI

ÖZET

Amaç: Öğrenci hemşireler için belirli stres yönetimi müdahalelerinin, iyi olma hissini artırabilecek farkındalık ve bilişsel değerlendirmelerin ôn planda tutulması önemlidir. Amacımız Türkiye'de hemşirelik öğrencilerinin stres indeksini, genel iyilik halini etkileyen parametrelerin değerlendirilmesidir.

Yöntem: Çalışmamız Trakya Üniversitesi hemşirelik lisans programından 695 öğrenciyle Aralık 2018- Ağustos 2019 arasında, 2 aşamalı olarak yapıldı. Illk aşamada öğrenciler "Hemşirelik öğrencileri stres ölçeği" (SNSI) ve "Genel Sağlık Anketi 12" (GHQ 12) ile değerlendirildi ve 695 öğrenci ile tamamlandı.

Bulgular: Katılımcıların \%65'i kız, \%34'ü erkekti. Öğrencilerin SNSI skoru 110; GHQ skorları 3.61'di. Kız öğrencilerin SNSI değeri 108,24; GHQ ise 3,60 bulundu. Erkeklerin SNSI değeri 114,05; GHQ ise 3,62 bulundu. KIz ve erkekler arasında SNSI değerleri için anlamlı fark saptanırken; GHQ skorları açısından fark bulunmadı. Mesleği kendi istekleriyle secenler ile ailelerinin istekleriyle seçenenler karşılaştırıldı. Kendi isteğiyle seçen 516 öğrencinin; hem SNSI, hem GHQ puanları daha iyiydi.

Sonuçlar: Çalışmamız Türkiye'de hemşirelik öğrencilerinde stres değerlendirmesi, genel sağlık değerlendirmesi için ya̧pılan en fazla katılımlı çalışmalar arasındadır. Hemşirelik lisans ögrencisi olmanın, stresli bir süreç olduğunu desteklemektedir. Sağlık hizmetinin yapıtaşı olan hemşireliğe adım atacak gençlerin stres ile etkileşimine farkındalığın arttırılması gerekliliğini göstermektedir.

Anahtar kelimeler: Hemşirelik öğrencileri; Stres; Hemşirelik öğrencileri stres indeksi; Genel sağlık ölçeği 12

\section{ABSTRACT}

Purpose: For student nurses, it's important to prioritize specific stress management interventions and to increase awareness of well-being and cognitive assessments. Our goal was to investigate the stress index of nursing students, and to evaluate parameters that affect the general well-being.

Methods and Materials: Our study was conducted in 3 stages between December 2018-August 2019 with 695 students from the nursing undergraduate program of Trakya University. In the first phase, the students were evaluated using the Student Nurse Stress Index (SNSI) and the second phase, General Health Questionnaire-12 (GHQ-12).

Results: The students' mean SNSI and GHQ-12 scores were 110 and 3.61, respectively. The female students' mean SNSI and GHQ-12 scores were 108.24; 3.60, respectively. The males' mean SNSI and GHQ-12 scores were 114.0; 3.62, respectively. Although there was a difference between males and females in terms of mean SNSI values, there was no difference between GHQ-12 scores. Among 516 students who chose nursing of their own will, both SNSI and GHQ-12 scores were better than those who chose nursing according to their families' wishes.

Conclusions: Our stress evaluation study in nursing students in Turkey is one of the most participatory works performed for general health assessment. It showed that being an undergraduate student is a stressful process. It's necessary to increase awareness about the interaction of young people who enter nursing, which is a cornerstone of health service.

Keywords: Student nurses; Student Nurse Stress Index (SNSI), General Health Questionnaire-12; stress 
$\mathbf{N}$ ursing is by nature a stressful profession. Stress has been shown to be highly likely to contribute to attrition in student nurses. It is an international issue to ensure that students continue nursing programs and that nurses do not leave the profession. Steps are now being taken in many countries to solve problems in nursing $(1,2)$. Evidence of factors contributing to the development of stress is increasing. Stress has been used as a common term to indicate psychological distress. Studies have examined the effects of stress on health and wellbeing of student nurses and nurses and there is increasing evidence that they are known to have higher levels of stress than other student populations (3) (4). Although student nurses do not have the same level of clinical responsibility as professional nurses, the experiences of student nurses seem to be stressful. It is therefore important to evaluate the stress experiences of student nurses because they may affect future career decisions and have a potential impact on the deterioration of the profession.

The determination of the overall scope of the impact of stress on student measurements has been problematic due to various approaches to stress measurement. The General Health Questionnaire (GHQ)-12 was used in many stress-related nursing studies and provides qualified results for comparisons. Some studies using this scale reported that more than half of the students had high levels of stress. Despite individual geographic and cultural characteristics, student nurses around the world share many common elements that can cause stress during their studies $(5,6)$.

In health vocational education, evaluation of hand function and skills is important in defining the level of performance of students in daily life activities and in revealing one's abilities. Hand skill levels are affected by genetic, social, and environmental factors, among others. Age, sex, education level, leisure activities, active working time, psychological factors, and the ability to work under pressure affect the change of hand skill levels. In shortterm motor activities, it was found that hand skill speed was independent of dominant hand preference and sex. Moreover, as stressors decrease and coping increases, hand skills tend to strengthen $(7,8)$. Awareness of increasing manual dexterity in health vocational education is increasing. Even under stress, good hand-eye coordination can be used and stress can be controlled, which is important in health service delivery.
The potential benefits of specific stress management interventions are emphasized for student nurses. More investment in stress management increases professional nursing competence $(9,10)$. To date, however, there is limited evidence to support the long-term benefits of such interventions. Recently, some studies suggested that stress in student nurses had an important effect on their lives (11). Individuals' ability to cope with stress is important in perceived situations. There is a significant difference between professional nursing and student nurses; as age decreases, it becomes more difficult to cope with stress and may make student nurses more vulnerable and susceptible to the negative effects of stress.

Student nurses may experience high levels of stress, especially during the first and subsequent stages of their training. It has been shown that student nurses use various coping strategies to cope with stressful situations; students may resort to avoidance coping strategies, including excessive alcohol intake during stressful times, more readily in men $(12,13)$.

Aim

Excessive stress levels can lead to physical and mental health problems and affect students' academic performance. Maintaining psychological well-being at good levels is important in many ways. Student nurse development, strong concentration, high confidence levels, and good sleep quality are important components of academic success. Our goal was to investigate the stress index of student nurses in Turkey, and to evaluate parameters that affect the general well-being.

\section{METHODS AND MATERIALS}

The study was conducted between December 2018 and June 2019 with 695 volunteer students from Trakya University nursing undergraduate program. Informed consent was obtained from all students who participated in the study.

Our study was planned in three stages. In the first stage, volunteer students were evaluated using the Student Nurse Stress Index (SNSI) and the second stage was the General Health Questionnaire-12 (GHQ-12). Sociodemographic characteristics were investigated.

The SNSI was used to measure the perceived stress level of the participants. The GHQ-12 was another measure of psychological well-being used to assess the quality of health in the students. The obtained SNSI and GHQ-12 
scores from the male and female students were evaluated. In addition, sociodemographic information such as age, class level, whether they stayed at home or in a dormitory during the school term and the high school where the student received a graduation diploma were investigated. They were asked about how many brothers/sisters they had. The students were also asked whether they chose the nursing profession themselves or if it was their parents' wish. In addition, they were questioned as to whether they thought they might be happy in the nursing profession in the future.

\section{Student Nurse Stress Index (SNSI)}

The SNSI is a reliable scale that is frequently used in the literature to specifically evaluate student nurses. It is a questionnaire consisting of 43 items developed to measure stress levels. Each item has a five-stage Likert scale response ranging from $1=$ not stressful to $5=$ extremely stressed. The scale defines four stress factors in student nurses: clinical, trust, education, and finance $(2,3)$.

The SNSI is a self-administered questionnaire with questions asking how stressful are the various aspects of being a student nurse. The SNSI scale was first developed in a study for student nurses in Scotland where the original factor structure was explored using exploratory factor analysis. Thirty-three of the original 43 items of the SNS were distributed to four factors related to the following aspects of stress: (1) clinic, (2) trust, (3) education, and (4) finance. This study was supported by the use of the same scale in a long-term study with student nurses in Hong Kong who responded to the SNSI. In these studies, it was determined that the stress measured using the SNSI, increased during student nurses' programs. The SNSI has been validated as a useful tool for measuring the stress of student nurses. Stress increases in nursing undergraduate education, and those who deal with stress more or less sufficiently have greater difficulties $(2,7,8)$.

\section{General Health Questionnaire 12 (GHQ 12);}

The GHQ-12 is a measure of current mental health status. Twelve items of the scale focus on two separate areas. They question the failure to perform normal functions and the existence of new experiences of distress. Each item describes a symptom related to psychological distress, anxiety and depression, and has four possible answers. The student is asked to choose 4 degrees for each question; (1) a zero score is given for $1 \mathrm{st}$ and 2 nd degree, and a score of 1 is given if one of the 3rd and 4th grades is selected. The overall score of the scale ranges from 0 to 12 ; the higher the score, the greater the morbidity. The GHQ-12 is a valid and reliable measurement scale for young people $(9,10)$.

The first two stages of the study were completed with 695 students. The sample of the descriptive cross-sectional study consisted of 609 undergraduate nursing students at Trakya University. Sociodemographic characteristics, parameters affecting stress levels, and health status were evaluated. There were 695 students in the first two stages of our study, and we completed the third stage with 306 students.

\section{Ethical statement}

Approval was obtained from the ethics committee of Trakya University Faculty of Medical Scientific Research (Decision Number: 2018/ 434-E291229).

\section{RESULTS}

Four hundred fifty-three students (65.20\%) were female and 242 (34.80\%) were male. The students were aged between 18 and 25 years. There were $438(63.00 \%)$ students aged 18-20 years and 257 (37.00\%) students aged 21-25 years. The sociodemographic characteristics of the students, stress levels during clinical practice and social life, and different stress levels according to sex and health status were evaluated.

The stress levels of the female and male students were evaluated. Students with chronic diseases and physical and psychological diseases were excluded from the study. The mean SNSI and GHQ-12 scores of the students participating in our study were 110 (SD: 32.12) and 3.61 (SD: $0.17)$, respectively.

The mean SNSI and GHQ-12 scores of the female students were 108.24 (SD: 33.68$)$ and 3.60 (SD: 0.17), respectively. The minimum SNSI score of the female students was 43 and the maximum score was 221 .

The mean SNSI and GHQ-12 scores of the male students were 114.05 (SD: 28.65) and 3.62 (SD: 0.20), respectively. The minimum SNSI score of the male students was 43 and the maximum score was 215 . The highest and lowest GHQ-12 scores in both sexes were found as 12 and 0 .

Mean SNSI values were found to be significantly different between the female and male students $(p=0.023)$. There was no significant difference in mean GHQ-12 scores $(p=0.953)$. 
When evaluated according to the academic year, 174 (25.00\%) students were 1st year, 244 (35.10\%) were 2nd year, 144 (20.70\%) were 3rd year, and 133 (19.10\%) students were 4th year. In terms of SNSI values, there was no significant difference between the academic years $(p=0.160)$. The mean SNSI score of year 1 was 106.60 (SD: 2.56), year 2 was 113.11 (SD: 2.09), year 3 was 111.88 (SD: 2.40), and year 4 was found as 108.09 (SD: 2.76).

The mean GHQ-12 score of year 1 was 3.16 (SD: 0.25), year 2 was 2.10 (SD: 0.25), year 3 was 4.04 (SD: 0.29), and year 4 was 2.83 (SD: 0.28). A significant difference was only found between the 2 nd year and 4 th year $(p<0.001)$.

The students were asked where they stayed during the school term; 141 (20.30\%) students were staying at home with their family or friends, and 554 (79.70\%) students lived in public or private dormitories. Of those who stayed at home with family or friends during the school term, the mean SNSI was 112.32 (SD: 2.52), and the mean GHQ-12 was 3.94 (SD: 0.30), and the mean SNSI and GHQ-12 of the students who lived in dormitories during the school term were 109.74 (SD: 1.38) and 3.52 (SD: 0.15). There was no significant difference between the two groups of students in terms of either SNSI $(p=0.395)$ or GHQ-12 $(p=0.227)$.

The scores of the students according to their high schools were examined. The mean SNSI and GHQ-12 scores of 196 (28.20\%) students who graduated from health vocational high school were 107.48 (SD: 2.47) and 3.72 (SD: 0.27), respectively. The mean SNSI and GHQ-12 scores of 499 $(71.80 \%)$ students who graduated from other high schools were 111.36 (SD: 1.39) and 3.56 (SD: 0.15), respectively. There was no significant difference according to the high school level in either SNSI $(p=0.152)$ or GHQ-12 $(p=0.612)$.

The SPSS 20.0 package program was used in all statistical analyses to evaluate the collected data. Data were analyzed with appropriate descriptive statistics. Numeric variables were analyzed with mean and standard deviation. Categorical variables were evaluated with frequency and percentage. The Shapiro-Wilk test was used to check the normality of the distribution of the data. The student's t-test was used for pairwise comparisons of the groups. The Chi-square test was used to assess the relationships between categorical variables. Descriptive statistics for numerical variables are given as mean and standard deviation. Descriptive statistics for categorical variables are given as percentages and frequency. In all statistical analyses, the significance level was determined as $5 \%$.
The SNSI and GHQ-12 scores of smokers and non-smokers were evaluated. The mean SNSI and GHQ-12 scores of students who smoked were 112.09 (SD: 1.46) and 3.95 (SD: $0.24)$, respectively. The mean SNSI and GHQ-12 scores of students who did not smoke were 106.86 (SD: 2.15) and 3.43 (SD: 0.16), respectively. There was a significant difference in SNSI scores ( $p=0.040)$, but not with GHQ-12 scores $(p=0.072)$.

When the students were examined according to the number of siblings they had, there was no significant difference between the SNSI $(p=0.531)$ and GHQ-12 $(p=0.062)$ scores.

The students who chose this profession with their own wishes and those who chose nursing according to their families' wishes were compared. The 516 students (74.20\%) who chose nursing undergraduate education with their own preference had a mean SNSI score of 106.22 (SD: 1.41) and the mean GHQ-12 score was 3.42 (SD: 0.16). There were significant differences in both the SNSI $(p<0.001)$ and the GHQ-12 ( $p=0.020)$.

Another issue that was asked to the students was their thoughts about the future. They were asked if they would be happy to stay in this profession in the future; 331 (47.60\%) students who thought they would be happy had mean SNSI and GHQ-12 scores of 103.06 (SD: 1.56) and 3.32 (SD: 0.17), respectively. The 331 (47.60\%) students who thought they might not be happy had mean SNSI and GHQ-12 scores of 118.19 (SD: 1.56) and 4.20 (SD: 0.21), respectively. There were significant differences between the two groups $(p<0.001)$.

\section{DISCUSSION}

Our study of stress assessment in undergraduate student nurses in Turkey is among one of the most participatory works performed for general health assessment. The findings support that being an undergraduate student in nursing is a stressful process.

In previous studies that evaluated stress levels and psychological morbidity in student nurses, stress levels were high and psychological well-being was low $(21,22)$. Our results agree with other studies examining psychological factors in student nurses. When the data obtained from our study were evaluated, it was seen that student nurses were stressed and they had a risk for attrition. In addition, the stress levels of our male students were higher than in female students. 
In Japanese student nurses, anxiety and depression have been reported in relation to the clinical component of their education (23). The students in our study had similar results to those in the Japanese study, scoring high on the GHQ-12. Sources of stress in European student nurses were systematically reviewed (24). It was seen that the awareness of the stress level increased in the students. Although studies have been conducted in different cultures at different times, they may represent cultural diversity in the perception and experience of stress among student nurses. The stress levels of student nurses change as the academic year changes. There are studies indicating that stress increases in advanced classes (25). However, our findings did not reflect this view. In addition, we observed that there were no changes in stress levels in different years of nursing undergraduate education. However, the first year students in our study did not comply with this generalization. The stress levels of the 2 nd and 3 rd year students were higher than in 1 st and 4th year students. In our study, it was observed that the 1st year students had just started to see themselves under the responsibility of being a student nurse. Our 4th year students had increased confidence in themselves with the pride of graduating in the near future. The SNSI (108.09) and the GHQ12 (2.83) scores were better than in the 2 nd and $3 r d$ year students.

There are similar findings in our study with studies reported in other student nurse populations (mean score 121.59). The SNSI scores were found to be higher in Chinese patients with chronic disease $(127.28 \pm 27.15)$ and the elderly (133.25 \pm 21.92$)(11)$, and it was observed that our student nurses and Chinese student nurses did not reach these grades $(3,26)$. Compared with a study conducted in Sweden (137.00 \pm 16.10$)$ (27), it was seen that the students in our study had better SNSI scores. The mean SNSI score of the students who participated in our study was $110 \pm 32.12$. From these findings, we thought that the relatively low level of welfare in our country might have increased the students' psychological resilience. There are also studies evaluating the well-being of student nurses by sex (28). In our study, stress levels of male student nurses were higher than in female students.

The difficulty of being a student nurse and working as a nurse continues in terms of workplaces and hospitals. An international study of five countries, including the United States of America and the United Kingdom, has shown that stress in working environments increases nurses' fatigue levels. A high degree of dissatisfaction among nurses is increasing worldwide (29).
To date, limited attention has been given to measuring Turkish student nurses' ability to cope with stress. Our study mainly focuses on the negative aspects of stress. Our study, using the SNSI, has demonstrated the need to raise awareness of the interaction of stress with young people who enter nursing, which is a cornerstone of healthcare.

Stress in professional nurses is not necessarily the same as in student nurses because there are different conditions. Student nurses do not bear the responsibilities of professional nurses and spend only very short periods in any clinical area. On the other hand, they probably have to adapt to a new way of life, i.e. after recently leaving school and home, and they need to study and pass exams as well as clinical assessments. Therefore, stress-related studies are especially needed in nursing students.

In these studies, SNSI and GHQ-12 levels have similar results to our findings. In a study conducted in China with 1538 student nurses, the mean SNSI and GHQ-12 scores were 105.11 (SD: 25.37) and 3.23 (SD: 2.54), respectively (25). The findings of this study are similar to our results. However, if we look at the scores of our students in Turkey, stress levels were slightly higher (SNSI: 110; GHQ-12: 3.61). As the number and quality of the practice areas and clinics increase, the level of education of undergraduate students will increase and stress levels will decrease.

Studies show that nurse educators have the potential to affect the perception of the difficulty of students in the nursing profession positively or negatively (32). Taking into account the potential stresses of student nurses, making appropriate changes in academic processes can help students. Failure to prepare properly for undergraduate studies will result in more stress, burnout, and fatigue than the profession itself. We believe that the focus of future research should address how a wide range of educators could help overcome the stressful experiences of undergraduate students.

The population is aging in many countries around the world. There is clearly a high demand for newly educated nurses for the aging population. However, there is evidence that many nurses leave the profession due to high levels of burnout and occupational stress $(25,33,34)$. Much attention needs to be paid to create a positive, workmotivating environment for student nurses. 


\begin{tabular}{|c|c|c|c|c|c|c|}
\hline \multirow[t]{2}{*}{ Parameters } & \multirow{2}{*}{\begin{tabular}{|l} 
Number \\
(n)
\end{tabular}} & \multirow{2}{*}{$\begin{array}{l}\text { Percentage } \\
(\%)\end{array}$} & \multicolumn{2}{|c|}{ SNSI** } & \multicolumn{2}{|c|}{$\mathrm{GHQ}^{* * *}$} \\
\hline & & & Mean (SD) & $\mathrm{p}$ & Mean (SD) & $p$ \\
\hline \multicolumn{7}{|l|}{ Age } \\
\hline $18-20$ & 438 & 63.00 & $109.41(1.55)$ & 0.360 & $3.69(0.17)$ & 0.417 \\
\hline $21-25$ & 257 & 37.00 & $111.72(1.96)$ & & $3.46(0.22)$ & \\
\hline \multicolumn{7}{|l|}{ Sex } \\
\hline Female & 453 & 65.20 & 108.24 & $0.023^{*}$ & 3.60 & 0.953 \\
\hline Male & 242 & 34.80 & 114.05 & & 3.62 & \\
\hline \multicolumn{7}{|l|}{ Classroom } \\
\hline 1 & 174 & 25.00 & $106.60(2.56)$ & 0.160 & $3.16(0.25)$ & $\begin{array}{l}0.001^{*} \\
(2 \text { and } 4)\end{array}$ \\
\hline 2 & 244 & 35.10 & $113.11(2.09)$ & & $4.10(0.25)$ & \\
\hline 3 & 144 & 20.70 & $111.88(2.40)$ & & $4.04(0.29)$ & \\
\hline 4 & 133 & 19.10 & $108.09(2.76)$ & & $2.83(0.28)$ & \\
\hline \multicolumn{7}{|l|}{ Place of residence } \\
\hline Home & 141 & 20.30 & $112.32(2.52)$ & 0.395 & $3.94(0.30)$ & 0.227 \\
\hline Dorm & 554 & 79.70 & $109.74(1.38)$ & & $3.52(0.15)$ & \\
\hline \multicolumn{7}{|c|}{ Graduation (High School) } \\
\hline Health Science & 196 & 28.20 & $107.48(2.47)$ & 0.152 & $3.72(0.27)$ & 0.612 \\
\hline Normal & 499 & 71.80 & $111.36(1.39)$ & & $3.56(0.15)$ & \\
\hline \multicolumn{7}{|l|}{ Smoking } \\
\hline Yes & 243 & 35.00 & $112.09(1.46)$ & $0.040^{*}$ & $3.95(0.24)$ & 0.072 \\
\hline No & 452 & 65.00 & $106.86(2.15)$ & & $3.43(0.16)$ & \\
\hline \multicolumn{7}{|l|}{ Number of siblings } \\
\hline $0-1$ & 304 & 43.70 & $111.13(1.96)$ & 0.531 & $3.90(0.20)$ & 0.062 \\
\hline$\geq 2$ & 391 & 56.30 & $109.59(0.20)$ & & $3.38(0.18)$ & \\
\hline \multicolumn{7}{|c|}{ Did they choose the profession of their own will } \\
\hline Yes & 516 & 74.20 & $106.22(1.41)$ & $<$ & $3.42(0.16)$ & $0.020^{*}$ \\
\hline No, family wanted & 179 & 25.80 & $121.91(2.15)$ & $0.001^{*}$ & $4.15(0.26)$ & \\
\hline \multicolumn{7}{|c|}{ Do they think you will be happy for life } \\
\hline Yes & 331 & 47.60 & $103.06(1.56)$ & $<$ & $3.32(0.17)$ & $<0.001^{*}$ \\
\hline No & 364 & 52.40 & $118.19(32.67)$ & $0.001^{*}$ & $4.20(0.21)$ & \\
\hline \multicolumn{7}{|c|}{$\begin{array}{l}\text { *Statistical significance } \\
\text { SD: Standard deviation } \\
\text { **SNSI: Student Nurse Stress Index } \\
\text { ***GHQ: General Health Questionnaire }^{* *}\end{array}$} \\
\hline
\end{tabular}


Table 2. The comparison of the results of the SNSI and GHQ-12 scales of our study and the Smith G, Yang F studies

\begin{tabular}{|c|c|c|c|c|c|c|c|c|}
\hline \multirow[t]{3}{*}{ Scales } & \multicolumn{6}{|c|}{ Our study } & \multicolumn{2}{|c|}{ Smith G, Yang F } \\
\hline & \multicolumn{3}{|c|}{ Female $(n=453)$} & \multicolumn{3}{|c|}{ Male $(n=242)$} & \multirow[t]{2}{*}{$p$} & \multirow[b]{2}{*}{ Mean (SS) } \\
\hline & Min & Max & $\begin{array}{l}\text { Mean } \\
\text { (SD) }\end{array}$ & Min & Max & $\begin{array}{l}\text { Mean } \\
\text { (SD) }\end{array}$ & & \\
\hline SNSI** & 43 & 221 & $\begin{array}{l}108.24 \\
(33.68)\end{array}$ & 43 & 215 & $\begin{array}{l}114.05 \\
(28.65)\end{array}$ & $\begin{array}{l}0.023 \\
*\end{array}$ & $105.11(25.37)$ \\
\hline $\mathrm{GHQ}^{* * *}$ & 0 & 12 & $\begin{array}{l}3.60 \\
(0.17)\end{array}$ & 0 & 12 & $\begin{array}{l}3.62 \\
(0.20)\end{array}$ & 0.953 & $3.23(2.54)$ \\
\hline
\end{tabular}

\section{CONCLUSIONS}

In addition to leaving the profession, students are also dropped out from nursing undergraduate programs. Concerns of health professionals about feeling unconfident are increasing all over the world. Higher education institutions should have mechanisms in place for recording attrition from programs. Steps should be taken to identify the reasons why student nurses do not wish to continue.

In order to improve the quality of education, it is necessary to reduce stress levels and encourage the active participation of students. Our study aimed to raise awareness of the stress levels and general well-being of student nurses. In order to provide accredited undergraduate nursing education with proven international validity and reliability, the current situation of students should be taken into consideration while preparing training programs. The needs of student nurses should be determined and positive and appropriate arrangements should be made in educational programs.

Further studies are needed on the relationship between psychological well-being, perceived stress, and how these factors may affect student outcomes. Evaluation of student nurses using the SNSI and GHQ-12 during their education will help to determine the level of well-being of the students during nursing degree programs. Furthermore, students from different cultures will provide a better understanding of the concepts of endurance, perceived stress, and psychological well-being of nurses. In addition, more qualitative studies can provide valuable insight into the stress experience during nurse training.

There is no conflict of interest in the study. No financial support was received for the study.
References

1.Gage $\mathrm{H}$. Keeping nurses nursing: a quantitative analysis. Nursing times. 2001;97(7):35.

2.Deary IJ, Watson R, Hogston R. A longitudinal cohort study of burnout and attrition in nursing students. Journal of advanced nursing. 2003;43(1):71-81. Crossref

3.Watson R, Deary IJ, Thompson DR, Li G. The stress in nursing students scale (SINS): principal components analysis of longitudinal data from Hong Kong. Journal of clinical nursing. 2010;19(7-8):1170-2. Crossref

4.Goff A-M. Stressors, academic performance, and learned resourcefulness in baccalaureate nursing students. International Journal of Nursing Education Scholarship. 2011;8(1). Crossref

5.Jones MC, Johnston DW. Distress, stress and coping in first-year student nurses. Journal of advanced nursing. 1997;26(3):475-82. Crossref

6.Pryjmachuk S, Richards DA. Predicting stress in pre-registration nursing students. British Journal of health psychology. 2007;12(1):125-44. Crossref

7.Mazloumi A, Rostamabadi A, Saraji JN, Foroushani AR. Work ability index (WAl) and its association with psychosocial factors in one of the petrochemical industries in Iran. Journal of occupational health. 2012:1202130234-. Crossref

8.Liu C-j, Marie D, Fredrick A, Bertram J, Utley K, Fess EE. Predicting hand function in older adults: evaluations of grip strength, arm curl strength, and manual dexterity. Aging clinical and experimental research. 2017;29(4):753-60. Crossref

9.Ranjbar H. Stress management: An ignored challenge in clinical nursing education. Nurse education today. 2016;36:10. Crossref

10. Eng C-J, Pai H-C. Determinants of nursing competence of nursing students in Taiwan: The role of self-reflection and insight. Nurse education today. 2015;35(3):450-5. Crossref

11. Silwal M, Gurung R, Gurung A, Sah I, Koirala D, Ojha S. Anxiety and Stress among B. Sc. Nursing First Year Students in a Selected Nursing College at Lekhnath, Pokhara, Nepal. Journal of Gandaki Medical College-Nepal. 2019;12(1):47-52. Crossref

12. Lo R. A longitudinal study of perceived level of stress, coping and self-esteem of undergraduate nursing students: an Australian case study. Journal of advanced nursing. 2002;39(2):119-26. Crossref

13. Klainin-Yobas $P$, Keawkerd $O$, Pumpuang W, Thunyadee $C$, Thanoi W, He HG. The mediating effects of coping on the stress and health relationships among nursing students: a structural equation modelling approach. Journal of advanced nursing. 2014;70(6):1287-98. Crossref 
14. Watson R, Deary I,Thompson D, Li G. A study of stress and burnout in nursing students in Hong Kong: a questionnaire survey. International journal of nursing studies. 2008;45(10):1534-42. Crossref

15. Watson R, Yanhua C, Ip MY, Smith GD, Wong TK, Deary IJ. The structure of stress: Confirmatory factor analysis of a Chinese version of the stressors in Nursing Students Scale (SINS). Nurse education today. 2013;33(2):160-5. Crossref

16. Goldberg DP. User's guide to the General Health Questionnaire. Windsor. 1988.

17. Goldberg D, Oldehinkel T, Ormel J. Why GHQ threshold varies from one place to another. Psychological medicine. 1998;28(4):915-21. Crossref

18. Allgöwer K, Kern C, Hermsdörfer J. Predictive and reactive grip force responses to rapid load increases in people with multiple sclerosis. Archives of physical medicine and rehabilitation. 2017;98(3):525-33. Crossref

19. Pryjmachuk S, Easton K, Littlewood A. Nurse education: factors associated with attrition. Journal of advanced nursing. 2009;65(1):149-60. Crossref

20. Ni C, Liu X, Hua Q, Lv A, Wang B, Yan Y. Relationship between coping, self-esteem, individual factors and mental health among Chinese nursing students: A matched case-control study. Nurse education today. 2010;30(4):338-43. Crossref

21. Shikai N, Shono M, Kitamura T. Effects of coping styles and stressful life events on depression and anxiety in Japanese nursing students: A longitudinal study. International Journal of Nursing Practice. 2009;15(3):198-204. Crossref

22. Papazisis G, Nicolaou P, Tsiga E, Christoforou T, Sapountzi-Krepia D. Religious and spiritual beliefs, self-esteem, anxiety, and depression among nursing students. Nursing \& health sciences. 2014;16(2):232-8. Crossref

23. Smith GD, Yang F. Stress, resilience and psychological well-being in Chinese undergraduate nursing students. Nurse education today. 2017;49:90-5. Crossref

24. Yang F, Bao JM, Huang XH, Guo Q, Smith GD. Measurement of resilience in $C$ hinese older people. International Nursing Review. 2015;62(1):130-9. Crossref

25. Lundman B, Strandberg G, Eisemann M, Gustafson Y, Brulin C. Psychometric properties of the Swedish version of the Resilience Scale. Scandinavian Journal of Caring Sciences. 2007;21(2):22937. Crossref

26. Kipping CJ. Stress in mental health nursing. International Journal of Nursing Studies. 2000;37(3):207-18. Crossref

27. Aiken LH, Clarke SP, Sloane DM, Sochalski JA, Busse R, Clarke H, et al. Nurses' reports on hospital care in five countries. Health affairs. 2001;20(3):43-53. Crossref

28. Sánchez-Camarero C, Ortega-Santiago R, Arias-Horcajadas F, Madoz-Gúrpide A, Miangolarra-Page JC, Palacios-Ceña D. Altered fine motor control and manual dexterity in people with cocaine dependence: An observational study. Australian occupational therapy journal. 2018. Crossref

29. Peters C, Chang A, Morales A, Barnes K, Alegretti A. An integrative review of assessments used in occupational therapy interventions for children with cerebral palsy/Revisão integrativa de avaliações utilizadas em intervenções de terapia ocupacional para crianças com paralisia cerebral. Cadernos Brasileiros de Terapia Ocupacional. 2019;27(1). Crossref
30. Alpers RR, Jarrell K, Wotring R. The subtle curriculum: What are we really teaching our students? Teaching and Learning in Nursing. 2012;7(2):78-9.

31. Lu H, Zhao Y, While A. Job satisfaction among hospital nurses: a literature review. International Journal of Nursing Studies. 2019. Crossref

32. Yearwood E, Riley JB. Curriculum infusion to promote nursing student well-being. Journal of advanced nursing. 2010;66(6):1356-64. Crossref 